\title{
The Role Of Religiousity and Religious Coping Towards Seeking Psychological Help Among College Students In Semarang
}

\author{
Diany Ufieta Syafitri, Laily Rahmah \\ Universitas Islam Sultan Agung Semarang \\ Corresponding Email: syafitridiany@gmail.com
}

\begin{abstract}
Mental health problems are increasingly prevalent in Indonesia, but many people are still reluctant to seek professional psychological help. Religiousity is considered as one of the factors that can influence one's preference for seeking psychological help, especially in Indonesian society, specifically in the city of Semarang, Central Java, which the life of society closely related to the value of religiousity. Therefore this study aimed to see the contribution of religiousity and religious coping in influencing the search for psychological help. This research was conducted at two universities, one state university and one Islamic private university which were determined through random sampling. Data collection was carried out online and offline with the Indonesian Islamic Psychological Measure of Islamic Psychology (I-PMIR), Islamic Religious Coping Scale (RCOPE), Attitude Towards Seeking Psychological Help (ATSPH), and Mental Health Seeking Help Intentions Scale (MHSIS) and obtained a total of 731 respondents. Multiple regression analysis showed that attitude was the strongest predictor of intention to seek psychological help $(B=0,556, p<0,01)$, followed by religious coping $(B=0,08, p<0,01)$, while religiousity was not a significant predictor. Further analysis showed the unique contribution of religious coping aspects towards the intention of seeking psychological help with $\mathrm{F}(5,725)=8,721, \mathrm{p}<0,01, \mathrm{R} 0,238$. There were also differences in the contribution of religiousity and religious coping to the intention of seeking psychological help based on the background of the respondent (state or private Islamic university) which discussed further in the article.
\end{abstract}

Keywords: Religiousity, Religious Coping, Seeking Psychological Help, College Students

\begin{tabular}{|c|c|c|c|c|}
\hline Submission & Review Process & Revised & Accepted & Published \\
\hline June 1, 2021 & $\begin{array}{c}\text { October 26, 2021 - } \\
\text { December 5, 2021 }\end{array}$ & December 7, 2021 & December 10, 2021 & December 29, 2021 \\
\hline
\end{tabular}

\section{Introduction}

One of the biggest challenge in preventing and effectively treating mental health disorders is the reluctance of people to seek help from professional mental health. Indonesia is one of the countries where most of its people have not utilize mental health services. This is shown by data from Basic Health Research (2018) which states that only 9\% of people with depression in Indonesia receive treatment. Furthermore, from the same source, out of all patients with severe mental disorders, $74.3 \%$ took medication, but only $48.9 \%$ took medication regularly for the past 1 month. In addition, Basic Health Research (2018) reported the existence of shackles for people with severe mental disorders. Most people also have low mental health literacy and there is a tendency to prefer non-professional informal help over professional help (Syafitri $\&$ Wijayanti, 2017). These various phenomena show that the Indonesian people have not been able to maximize the available mental health (psychological) services.

Several other studies related to seeking psychological help show that only about $30 \%$ of people with mental health disorders seek psychological help and the others seek informal help either from religious sources, family, or friends (Brown et al., 2014). Research on black male subjects showed that $33 \%$ used professional services and informal 
support, $14 \%$ relied on informal support, and 29\% did not seek help (Woodward et al., 2012). Furthermore, for African American women, data showed that $47 \%$ use a combination of professional services and informal support, only $14 \%$ use professional services, $2 \%$ use informal support, and $16 \%$ do not seek help (Sosulski \& Woodward, 2013).

The construct of seeking psychological help was first introduced by Mechanic (1962) with the term "illness behavior" which refers to healthy human behavior which consists of the way a person observes his body, identifies and understands symptoms, takes preventive action or treatment, or utilizes service systems. health. Furthermore, in 1970 the first theory related to attitudes towards psychological help and its measurement tools was developed by Fischer \& Turner (1970), in which attitudes towards seeking psychological help consist of four components which as follow (a) perception of recognition of the need for professional psychological help, (b) ) tolerance for the stigma associated with seeking psychological help, (c) openness of a person regarding the problems experienced, (d) confidence in the ability of professional psychological services to assist.

Some of the early studies related to seeking professional psychological help was carried out by Kelly \& Achter (1995) and Cepeda-Benito \& Short (1998) who created a psychological help-seeking model, in which the results generally indicated that levels of distress, availability of social support, selfisolation, and attitudes toward counseling became a significant predictor of seeking psychological help behavior in college students. In addition to the predictors above, subsequent study demonstrated the importance of culture in seeking professional psychological help. The results of research by Kim \& Omizo (2003) indicate that attitudes towards counseling are mediated by the relationship between attachment to Asian values (adherence to Asian values) and willingness to attend counseling.

In subsequent studies, not only culture but it was also found that religious factors also played an important role in seeking psychological help. Some researchers argue that religiousity is a culturally relevant factor that is under-explored in research related to seeking psychological help (Sabina et al., 2012; Wamser et al., 2011). In this case, especially how are the attitudes and behavior of seeking help towards religious figures and mental health professionals (Crosby \& Bossley, 2012). It is important to be recognized because religion is not just another variable in explaining the seeking psychological help, but also an alternative view of life about the meaning of suffering and what considered as an appropriate treatment. Furthermore, religion plays an important role, especially in religious populations, religious factors are very important in determining how to deal with psychological problems (Wamser et al., 2011).

There are at least two main reasons why religion is one of the factors that influence the seeking for psychological help. The first reason, apart from the community's familiarity with religious figures through worship activities (eg recitation, congregational prayers, church services, etc.), is the religious gap between clients who have religious beliefs and mental health professionals. Clients are very likely to perceive a difference between their belief system and the therapist (psychologist/psychiatrist) thus this can create barriers to seeking help (Abe-Kim et al., 2004a). In addition, there is a more serious dilemma experienced by clients, which is the concern of whether or not to discuss their religious views in the therapeutic process, and the secular therapy process is feared to weaken their faith (Mayers et al., 2007). 
In Indonesian society itself, reasons related to religion are also often a source of dilemma for clients to consult with psychologists, for example concerns about exposing themselves and others (Hardika, 2020). This is based on the hadith:

"If someone covers the disgrace of another person in this world, Allah will cover his disgrace on the Day of Resurrection" (HR. Muslim No 4692).

In addition, recently there has also been a debate about the causes of a psychological disorder, whether it is caused by problems of religiousity and spirituality or psychological. There is a lot of discussions on social media regarding depression, whether it is due to lack of faith or due to psychological causes. Some consider depression to be caused by a lack of faith (lack of religiousity and spirituality), consider psychological help to be unimportant, and the problem to be solved simply by increasing worship and asking the ustadz (Islamic religious teacher) for help (Mabruroh, 2020). The two phenomena related to religiousity above show that religious views contribute to attitudes towards seeking professional psychological help.

The results of other studies showed the importance of religious factors in seeking psychological help, especially for Muslim subjects which reinforces the view that Muslim communities in other countries also tend to use religious help, for example Al-Krenawi, et al (2004) showed that Muslim female students in Jordan mostly choose religious coping as a way of dealing with problems. This result was also found by Al-Darmaki, et al (2016) in Arabic. In British respondents, Loewenthal et al., (2001) showed that Muslim respondents had the greatest belief in the effectiveness of religious coping for depression and had lower intentions to seek professional psychological help. The results of Syafitri's research (2019) on college students in Semarang city show that the parties who are asked for the most help are family, close friends, followed by the ustadz, also Allah SWT. Furthermore, the results of research by Syafitri (2018) and Syafitri \& Wijayanti (2017) also among college students in Semarang City indicate that there is a religious factor in seeking psychological help where the choice of seeking help from religious sources (God, ustadz, religious experts) occupies the second-highest choice after psychologists and respondents also indicated that they prefer seeking religious help over professional mental health help, most respondents practice religious coping as a way of dealing with psychological problems.

On the other hand, the results of research related to the contribution of religiousity to seeking psychological help are still inconsistent. The results of a study in Filipino communities living in the United States showed that high religiousity was associated with seeking help from religious figures, but did not decrease help-seeking behavior among mental health professionals (Abe-Kim et al., 2004b). Similarly, the results of research on Latin American communities in the United States show that individuals with high religiousity show greater reluctance to use formal mental health services (Moreno \& Cardemil, 2016), but the results of subsequent studies in similar populations show that both religious and religiousity does not affect attitudes towards formal mental health services (Moreno et al., 2017). The results of the study in Turkey showed that the relationship between religiousity and attitudes towards psychological services was fully mediated by family values, where if the variable family values were added to the model, the relationship between religiousity and attitudes towards psychological services was no longer significant (Rogers-Sirin et al., 2017).

Based on the explanation above, it can be concluded that religiousity seems to 
contribute to seeking psychological help, although the results of this study seem inconsistent. In addition, the results of existing research are mostly based on minority respondents in a country, not in their native country, so there is an acculturation factor not just religion in it. Therefore, this study aimed to determine the relationship between religiousity, religious coping, attitudes, and intentions of seeking professional psychological help on student subjects in Semarang City. Study related to religious factors in seeking psychological help in Indonesia, especially with respondents from Muslim backgrounds, is rarely carried out, even though as explained above, religious factors play an important role in seeking psychological help, so it is necessary to conduct research related to the role of religious factors such as religiousity and coping religious attitudes toward seeking psychological help. Moreover, Indonesia is a country where most of the people are attached to religious values. Knowledge of how religiousity and religious coping relate to attitudes and intentions to seek psychological help can help mental health professionals gain insight into how to build stronger connections with clients who have a strong religious background and increase sensitivity to religiousity in practicing psychology (Turner). et al., 2019). It is hoped that this research can provide an explanation of the dynamics of religious factors in seeking psychological help so that they can provide recommendations for designing a mental health system that is following the religious context of the Indonesian people.

Religiousity in this case is religiousity in the context of Islam. There have been many theories related to religiousity that exist, but they are considered less accommodating to Islamic values. Therefore, the theory used here is based on the theory of Islamic religiousity based on studies of the Qur'an and hadith. From an Islamic perspective, religion is the relationship between God as the real reality and His creation, where humans are one of His creations. In Islam, religion is considered as a way or way of life with God as an anchor that includes everything related to the life, faith, and identity of a Muslim (Diana et al., 2016). Islamic teachings are comprehensive teachings that cover all aspects of a Muslim's life. Several things can be used as benchmarks for a Muslim's religiousity, which are 1) the pillars of faith such as belief in Allah, angels, the books of Allah, prophets, the last day, and qada and qadar, 2) the implementation of worship such as prayer, hajj, umrah, almsgiving, fasting, reading the Qur'an, good deeds such as humility, respecting parents, treating others fairly, helping neighbors, avoiding forbidden acts such as eating pork, drinking alcohol, avoiding premarital sex, and the universality of Islam such as views that every Muslim in the world is a family, understands the suffering of Muslims around the world (Raiya et al., 2008).

Furthermore, religious coping is defined as an attempt to understand and deal with the pressures of life in a way that is related to what is considered sacred. The term sacred here does not only refer to God or a greater power but also other aspects of life-related to divinity or things that are considered God (Pargament et al., 2011). This study used Muslim subjects, so that religious coping, in this case, is measured in the context of Islam. There is an emphasis in Islamic literature on using religious beliefs and worship as a means of dealing with difficulties in life. Based on this, there are five aspects of Islamic religious coping which were adapted by Aflakseir \& Coleman (2011) from the theory of religious coping belongs to Pargament, et al., (2011) which consist of a) practice (the practice of worship rituals) which are rituals of worship 
such as prayer, praying, following recitation, and so on as a way of dealing with problems, b) benevolent reappraisal (a full assessment of wisdom) is a reassessment of existing problems from a religious point of view so that they can take the meaning of the problem, c) negative feelings towards God (bad feelings towards God) such as bad feelings towards God because they feel that the problem that occurs is a form of punishment from God and God has forgotten them, d) passive coping (passive coping), which the individual surrenders everything to God and waits for God to solve it, and e) active coping (active coping), that is the individual actively try to solve the problem as best as possible and leave the rest to God.

\section{Research Methods}

The method used in this study is a correlational quantitative survey conducted online using Google Forms and offline platforms. The subjects in this study were students in Semarang city. The stages of the research are 1) adaptation of measurement instruments, 2) tryout of measurement instruments, 3) analysis of tryout data, 4) data collection, and 5) analysis and reporting.

The subjects of this study were college students in the city of Semarang obtained through cluster random sampling. The clusters used are state universities and private Islamic universities (regarding research variables related to Islamic religiousity, the respondent's criteria are Muslims). Furthermore, it was chosen randomly on Islamic public and private universities in Semarang City, so that University A (UA) was obtained as a sample from the cluster of state universities and University B (UB) from the cluster of Islamic private universities., Questionnaires were distributed through the Google Forms link and directly to students enrolled in 2018-2019 in all faculties at the two universities. The reason for choosing these two generations was that when data collection was carried out, the two generations had undergone college for 3-5 semesters that they were considered to have sufficient experiences in living as college students. These students different from the students enrolled in year 2020, which were only several months undergoing college life, especially the lectures mostly done online due the pandemic situation.

The number of UA students class 20182019 was around 14,000 students, while UB is around 6000. If it is assumed that the population used is only half (50\% class 2018 and $50 \%$ class of 2019), then the total population of UA is 7000 students and UB is 3000 students. With a $95 \%$ confidence level, 365 samples were needed for UA and 341 for UB. The data collection process was carried out by incidental sampling because it was not possible to do stratified sampling.

\section{Research Instruments}

a. Indonesian Psychological Measure of Islamic Religiousity (I-PMIR)

This scale was constructed by Salsabila, Rofifah, Nathanael, \& Ramdani (2019) which measures the religiousity of the Indonesian version of Islam with 52 items. The reliability coefficient of Alpha Cronbach on this scale ranges from 0.769 to 0.929 .

b. Islamic Religious Coping (RCOPE)

This scale was constructed by Aflakseir \& Coleman (2011), consisting of 22 items. The reliability estimation of the religious coping scale was obtained using a Cronbach Alpha reliability coefficient of 0.848. (Sulistyani et al., 2018).

c. Mental Health Seeking Help Intentions Scale (MHSIS)

MHSIS constructed by Hammer \& Spike (2018), this tool measures the intention to seek psychological help with three items 
that measure respondents if they experience mental health problems. The reliability test using Cronbach's Alpha internal consistency produces a coefficient of 0.953 with discrimination index ranging between 0.858-0.922.

d. Attitude Towards Seeking Psychological Help Scale (ATSPH)
This scale consists of 29 items with the internal consistency reliability of this scale is 0.83 to 0.86 (Fischer \& Turner, 1970). In 2019 this scale has been adapted and tested on college student subjects in Central Java with a Cronbach Alpha reliability coefficient of 0.726 (Syafitri \& Kusumaningsih, 2021).

\section{Results and Discussion}

1.UA

Table 1. Respondent Demographics UA

\begin{tabular}{|c|c|c|}
\hline \multicolumn{2}{|c|}{ Description } & \multirow[t]{2}{*}{ Total } \\
\hline Sex & & \\
\hline & Male & 96 \\
\hline & Female & 290 \\
\hline \multicolumn{3}{|l|}{ Age } \\
\hline & $17-19$ & 195 \\
\hline & $20-22$ & 191 \\
\hline \multicolumn{3}{|l|}{ Class of } \\
\hline & 2017 & 2 \\
\hline & 2018 & 166 \\
\hline & 2019 & 218 \\
\hline \multicolumn{3}{|l|}{ Domain } \\
\hline & Central Java & 297 \\
\hline & West Java & 37 \\
\hline & East Java & 8 \\
\hline & DKI Jakarta & 14 \\
\hline & DI Yogyakarta & 9 \\
\hline & Banten & 7 \\
\hline & Central Kalimantan & 1 \\
\hline & East Kalimantan & 2 \\
\hline & West Sumatera & 4 \\
\hline & North Sumatera & 1 \\
\hline & South Sumatera & 1 \\
\hline & West Nusa Tenggara & 1 \\
\hline & Kepulauan Riau & 2 \\
\hline & Lampung & 2 \\
\hline \multicolumn{3}{|l|}{ Faculty } \\
\hline & Psychology & 21 \\
\hline & Engineering & 54 \\
\hline & Medicine & 42 \\
\hline & Social and political science & 61 \\
\hline & $\begin{array}{c}\text { Animal science and } \\
\text { agriculture }\end{array}$ & 37 \\
\hline & Public Health & 25 \\
\hline & Economy and business & 31 \\
\hline & Cultural Science & 40 \\
\hline
\end{tabular}


Matemathics and Science $\quad 27$

Law 9

Fisheries and marine science $\quad 22$

Vocational School 17

Total 386

2.UB

Table 2. Respondent Demographics UB

\begin{tabular}{|c|c|c|}
\hline \multicolumn{2}{|r|}{ Descriptions } & \multirow[t]{2}{*}{ Total } \\
\hline Sex & & \\
\hline & Male & 96 \\
\hline & Female & 249 \\
\hline \multicolumn{3}{|l|}{ Age } \\
\hline & $17-19$ & 133 \\
\hline & $20-22$ & 206 \\
\hline & $23-26$ & 6 \\
\hline \multicolumn{3}{|l|}{ Class of } \\
\hline & 2017 & 5 \\
\hline & 2018 & 117 \\
\hline & 2019 & 180 \\
\hline \multicolumn{3}{|l|}{ Domain } \\
\hline & Central Java & 308 \\
\hline & West Java & 10 \\
\hline & North Java & 8 \\
\hline & Banten & 3 \\
\hline & DKI Jakarta & 1 \\
\hline & East Kalimantan & 1 \\
\hline & Central Kalimantan & 2 \\
\hline & West Kalimantan & 1 \\
\hline & Lampung & 3 \\
\hline & Kepulauan Riau & 4 \\
\hline & South Sulawesi & 1 \\
\hline & South Sumatera & 1 \\
\hline & North Sumatera & 1 \\
\hline & Not mentioned & 1 \\
\hline \multicolumn{3}{|l|}{ Faculty } \\
\hline & Economy & 56 \\
\hline & Islamic Religion & 15 \\
\hline & Language and communication & 18 \\
\hline & Medicine & 79 \\
\hline & Dentistry & 12 \\
\hline & Psychology & 61 \\
\hline & Engineering & 25 \\
\hline & Law & 26 \\
\hline & Education & 33 \\
\hline & Nurse & 20 \\
\hline & Total & 345 \\
\hline
\end{tabular}


Table 3. Data Description

\begin{tabular}{ccccc|ccccc|cccc}
\hline \multirow{2}{*}{ Variable } & \multicolumn{4}{c}{ UA } & \multicolumn{4}{c}{ UB } & \multicolumn{4}{c}{ Combined } \\
\cline { 2 - 17 } & Min & Maks & Mean & SD & Min & Maks & Mean & SD & Min & Maks & Mean & SD \\
\hline IPB & 3 & 21 & 14.7 & 4.8 & 3 & 21 & 14.3 & 4.4 & 3 & 21 & 14.5 & 4.7 \\
RE & 129 & 228 & 204.2 & 12.4 & 133 & 238 & 206.7 & 13.6 & 129 & 238 & 205.4 & 13.07 \\
SPB & 11 & 35 & 25.1 & 4.9 & 12 & 35 & 25.5 & 4.07 & 11 & 35 & 25.3 & 4.5 \\
RK & 29 & 90 & 74.9 & 8.8 & 46 & 90 & 74.8 & 8.3 & 29 & 90 & 74.9 & 8.6 \\
\hline
\end{tabular}

IPB $=$ Intention to Seek Psychological Help, RE $=$ Religiousity, SPB = Attitude towards Seeking Psychological Help, and RK = Religious Coping

Table 4. Matriks corelation

\begin{tabular}{|c|c|c|c|c|c|c|c|c|c|c|c|c|}
\hline \multirow{2}{*}{ Variable } & \multicolumn{4}{|c|}{ UA } & \multicolumn{4}{|c|}{ UB } & \multicolumn{4}{|c|}{ Combined } \\
\hline & 1 & 2 & 3 & 4 & 1 & 2 & 3 & 4 & 1 & 2 & 3 & 4 \\
\hline IPB & - & & & & - & & & & - & & & \\
\hline $\mathrm{RE}$ & 0,062 & - & & & $0,182 *$ & - & & & $0,113^{*}$ & - & & \\
\hline SPB & $0,552^{*}$ & 0,032 & - & & $0,547^{*}$ & 0,068 & - & & $0,546^{*}$ & 0,051 & - & \\
\hline RK & 0,094 & $0,752 *$ & $-0,004$ & - & $0,233^{*}$ & $0,66^{*}$ & 0,087 & - & $0,154^{*}$ & $0,702 *$ & 0,033 & - \\
\hline
\end{tabular}

From Table 4 above, it can be seen that in the UA subject, there was no significant correlation between RE and RK on IPB and SPB. On the other hand, this is found in the subjects of UB and the combined subjects of the two universities. Furthermore, it can be seen that a significant correlation is only found between RK and RE with IPB, not SPB, except for UB subjects.

The data analysis was continued with multiple regression to determine the contribution of all dependent variables to IPB. The results show that the model is acceptable $(\mathrm{F}(3.725)=112, \mathrm{p}<0.001, \mathrm{R} 0.563)$ with an effective contribution of $31.7 \%$. Furthermore, it can be seen that the strongest predictor is SPB with (B = 0.556 95\% CI [0.49, 0.61], SE $=0.03, \mathrm{t}=17.6, \mathrm{p}<0.001)$ and $\mathrm{RK}$ even though the Beta coefficient is different. very small (B $=0.0895 \%$ CI $[0.03,0.128] \mathrm{SE}=0.02, \mathrm{t}=$ $3.536, \mathrm{p}<0.001)$.

Furthermore, regression analysis was performed to determine the contribution of RE and RK to SPB and IPB. With SPB as the independent variable, it is known that the model cannot describe the data $(\mathrm{F}(2.726)=$ 0.952 , p 0.378). Furthermore, with IPB being the dependent variable, multiple regression results show that the model is able to describe the data $(\mathrm{F}(2,726)=9.025, \mathrm{p} 0.00, \mathrm{R} 0.156)$ with an effective contribution of $2.4 \%$, where $\mathrm{RK}$ is a significant predictor $(\mathrm{B}=0.08195 \% \mathrm{CI}$ [0.026, 0.136], $\mathrm{SE}=0.02, \mathrm{t}=2.915, \mathrm{p}<0.01$ ) while RE was not. The analysis was continued by looking at the contribution of the RK aspect to IPB, with the results showing that the model was able to explain the dependent variable ( $\mathrm{F}$ $(5,725)=8.721, \mathrm{p}<0.01, \mathrm{R} 0.238)$ with an effective contribution of $5.6 \%$, where aspect 2 $(\mathrm{B}=0.21195 \%$ CI [0.07, 0.324], $\mathrm{SE}=0.06, \mathrm{t}=$ $3.16, \mathrm{p}<0.01)$, aspect $3(\mathrm{~B}=0.13995 \% \mathrm{CI}$ $[0.00,0.276], \mathrm{SE}=0.06, \mathrm{t}=2, \mathrm{p}<0.05)$, and aspect $4(\mathrm{~B}=-0.44695 \% \mathrm{CI}[-0.72,-0.166]$, $\mathrm{SE}=-.142, \mathrm{t}=-3,13, \mathrm{p}<0.01)$ was a significant predictor, while aspects 1 and 5 were not.

Additional analysis was carried out to see the role of RE and RK on IPB in each university. No analysis was carried out with SPB as the 
dependent variable because the results of product-moment correlation and regression with the overall subject showed RE and RK, and their aspects did not contribute to SPB.

a. Multiple regression analysis of UA subjects, with RE and RK as predictors and IPB as dependent variables

The results of multiple regression with RE and RK as predictors showed that the model could not describe the data $(\mathrm{F}(2.381)=1.806, \mathrm{p}<0.166)$. The analysis is continued by looking at the contribution of the RK aspects, namely the results of multiple regression analysis indicate that the model fits the data $(F(5.380)=5.924$, $\mathrm{p}<0.01, \quad \mathrm{R}$ 0.269), with an effective contribution of $7.23 \%$ where aspect $2(\mathrm{~B}=$ $0,26195 \%$ CI $[0,08,0441] \mathrm{SE}=0,09, \mathrm{t}=$ $2,848, \mathrm{p}<0,05)$, aspect $3(\mathrm{~B}=0,21495 \% \mathrm{CI}$ $[0,02,0,407], \mathrm{SE}=0.09, \mathrm{t}=2.182, \mathrm{p}<0.05)$, and aspect $4(\mathrm{~B}=-0.84495 \% \mathrm{CI}[-1.25$, 0.437], $\mathrm{SE}=0.2, \mathrm{t}=-4.079 \mathrm{p}<0,01)$ become a significant predictor for IPB.

b. Multiple regression analysis of UB subjects, with RE and RK as predictors and IPB as dependent variables

The results of multiple regression analysis with RE and RK as predictors showed that the model could explain the data $(\mathrm{F}(2.342)$ $=10.118, \mathrm{p}<0.01, \mathrm{R} 0.236)$ with an effective contribution of $5.5 \%$, where RK was a significant predictor $(\mathrm{B}=0.107$, $\mathrm{p}<0.01)$ while RE is not. The analysis is continued by looking at the contribution of the RK aspects to IPB, namely the results of multiple regression analysis indicate that the model fits the data (F (6.701, $\mathrm{p}<0.01, \mathrm{R}$ $0.3)$ with an effective contribution of $9 \%$, where aspect $5(\mathrm{~B}=0.52895 \%$ CI $[0.16$, 0.88 ], $\mathrm{SE}=0.18, \mathrm{t}=2.890, \mathrm{p}<0.01)$ was a significant predictor while the other aspects were not.

c. Differences between SPB and IPB by gender
Based on the analysis conducted through ANOVA, there was a significant difference in the level of SBP by sex with F 18.745 , $\mathrm{p}<0.01$, where women (mean 25.7) had a higher attitude towards psychological help than men (mean 24. ,06). Likewise, in IPB there was a significant difference based on gender with F 28.828, p $<0.01$, where women (mean 15.01) had a higher intention to seek psychological help than men (mean 13.02).

d. Religiousity and religious coping

Based on the results of the correlation matrix in table 4 above, it can be seen that the product moment correlation between religiousity and religious coping is 0.702 with an effective contribution of $49.2 \%$.

e. Differences between the level of religiousity and religious coping by university

Based on the analysis conducted through ANOVA, there is a significant difference in the level of religiousity between UA and UB with F 7.092, p <0.01, where Unissula respondents (Mean 206.7) have higher religiousity than UD (Mean 204.16) . On the other hand, there is no significant difference in religious coping in terms of the type of university (F 0,048, p 0,826).

Multiple regression analysis was carried out with all residuals forming a normal distribution and homogeneous variance. Detection of outliers through Cook's Distance shows that if outliers are not included in the analysis, then the mean, median, and standard deviation are less than $1 \mathrm{SD}$ so they are considered not to interfere with the regression line.

This study aimed to examine the relationship between religiousity, religious coping, attitudes, and intentions towards seeking professional psychological help. The results of multiple regression analysis showed that among the three dependent variables, attitude is the strongest predictor, followed by 
religious coping even though the Beta value is small. On the other hand, religiousity does not appear to be a significant predictor. This supported the theory of planned behavior which shows that attitude is one of the main predictors of intention (Ajzen, 2012). The results of a study on university students in Botswana showed that attitudes and stigma towards psychological help significantly predict psychological help-seeking intentions (Pheko et al., 2013).

Next, a separate analysis was conducted to determine the role of religiousity and religious coping on attitudes and intentions. On attitudes toward seeking psychological help as the dependent variable, the results showed that neither religiousity nor religious coping was a significant predictor. This was also found by several other studies which showed that religiousity and religious coping did not significantly predict attitudes (Moreno et al., 2017; Rogers-Sirin et al., 2017). On the other hand, the results of the analysis with intention as the dependent variable show different things, where even though religiousity is still not a significant predictor, religious coping can be a significant predictor even with a small Beta value. This indicates that religious coping is directly related to intention, rather than attitude. It can also be seen in Table 4 where there is no significant correlation between religiousity and attitude, while there is a significant correlation between religiousity and religious coping with intentions. The results of previous studies also showed that spirituality was positively and significantly the strongest predictor of the intention to seek counseling help and help-seeking behavior in black respondents in the United States (Rougier, 2011). Research in other fields has also shown that religiousity directly predicts proenvironmental intentions (Wang et al., 2020).

Further analysis showed that the religious aspects of coping are 1) practice (the practice of worship rituals), 2) benevolent reappraisal (full assessment of wisdom), 3) negative feelings towards God (bad feelings towards God), 4) passive coping (passive coping). , and 5) active coping contributed more to the intention to seek help, 5.6\%. Aspect 4 was the predictor with the largest Beta, followed by aspects 2, and 3. Aspect 4 had a negative Beta value, describing passive coping. Where humans tend to rely on God to solve their problems without any personal effort. This is in line with the results of research by Wamser, Vandenberg, \& Hibberd (2011) which states that the type of deferred coping, in which God is expected to intervene and help one's difficulties, is associated with a preference for religion over psychological help. Furthermore, aspect 2 describes the individual's ability to reassess the problems experienced and take a positive religious meaning, where this aspect contributes significantly to the intention to seek psychological help. The study results supported this, where the use of problemsolving coping such as positive reframing is associated with greater tolerance for stigma and greater trust in psychological help (Niegocki \& gisdóttir, 2019).

Aspect 3 describes negative emotions towards Allah where the individual perceives Allah as ignoring him and not answering his prayers. This aspect measures aspects of negative religious coping, namely considering existing problems as punishment, spiritual and religious dissatisfaction (Aflakseir \& Coleman, 2011). This predictor has a positive direction which means that the more negative emotions a person has towards God, the more likely they are to seek professional psychological help. This is also supported by the results of research on Latin American women which showed that negative religious coping increased the likelihood of seeking formal help (Sabina et al., 2012). 
The explanation above shows that the religious aspects of coping uniquely contribute to the intention to seek psychological help. According to Pargament, Feuille, \& Burdzy (2011), religious coping is multimodal or many methods, both behavioral, emotional, relationship, and cognitive, have a helpful or detrimental impact and therefore have different influences on the coping process itself. Furthermore, religious coping is conceptualized into three categories, namely self-directing which is control through oneself, deferring or surrendering and seeking control through God, and control through a relationship with God (collaborative), where the results of empirical research support the three religious coping styles ( Phillips III et al., 2004). Through this study, it can be seen that aspects of the religious coping of RCOPE used are supported in this study, where certain coping styles contribute to the intention to seek psychological help. In this case, passive, active religious coping aspects, benevolent judgments, and negative feelings toward God each contribute to intentions.

Furthermore, it can be seen that there is a significant difference in religiousity between UA and UB subjects. This can be understood since UA is an Islamic university that emphasizes the emphasis on Islamic teachings both at the academic level and in the daily lives of its students. However, this has implications for the relationship between religiousity and religious coping with attitudes and intentions to seek psychological help. From Table 4, it can be seen that there is no significant relationship between religiousity and religious coping with attitudes and intentions on UA subjects. On the other hand, in UB subjects, a significant correlation was found between religiousity and religious coping to seek psychological help. The results of multiple regression analysis showed that religiousity and religious coping could not predict intentions in UA subjects, while in UB religious coping subjects were significant predictors. However, multiple regression analysis on UA with religious coping aspects as predictors showed that the five aspects contributed to the intention, where aspects 2, 3, and 4 were significant predictors with an effective contribution of $7.23 \%$. This also occurs in UB subjects, where only aspect 5 is a significant predictor with an effective contribution of $9 \%$. These findings indicate that the environment affects a person's religiousity, which is related to his attitude and intention to seek psychological help. It can also be seen that in subjects with high religiousity and religious backgrounds, coping religiousity is a predictor of the intention to seek psychological help, while in subjects without religious backgrounds is not happening.

Table 4 it can also be seen that there is a significant positive relationship with a fairly large correlation value between religiousity and religious coping. This is consistently found in both UA, UB, and combined subjects. The effective contribution of religiousity to religious coping is about $49.2 \%$. The results of the research by Moreno, Nelson, \& Cardemil (2017) also show the same thing where there is a positive and significant correlation between religiousity and religious coping both internally and externally. This indicates that religiousity significantly predicts the use of religious coping, where according to the results of this study religious coping will predict the intention to seek psychological help.In this study, contrary to what was expected, it can be seen that religiousity is not a significant predictor of both attitudes and intentions to seek psychological help. The results of research by Crosby \& Bossley (2012) on university students in the United States showed that religiousity was negatively related to attitudes towards seeking psychological help, as well as the results of research by Wamser et al. (2011) on Orthodox Christian respondents also showed that religious fundamentalism 
was associated with higher preferences. greater on religious than on psychological help. This study shows different results, which may be caused by differences in measuring instruments where the two studies above use different measuring instruments, so they may measure different constructs of religiousity. In the study by Crosby \& Bossley (2012) using measurements of religious involvement (religious involvement) and the Dimensions of Religiousity Scale which measures religiousity through the cognitive-emotional paradigm, while research by Wamser, et al., (2011) uses the Religious Fundamentalism Scale and Religious Screening to measure the level of subject religiousity. Based on this, it is recommended for future research to measure not only the level of religiousity but also religious fundamentalism or religious involvement. This is because the character of the subject with high religious fundamentalism, psychological treatment is considered as something that is not suitable with their view of life, so this will hinder the subjects' intention in seeking professional help (Wamser et al., 2011).

Differences were also found in attitudes and intentions to seek psychological help in terms of gender, where women had higher attitudes and intentions than men. Research results consistently show that women have more positive attitudes and intentions towards psychological help than men. This was also found by Syafitri \& Kusumaningsih (2021), we're on the subject of students in Semarang City, women have a more positive attitude towards online and face-to-face counseling. Other studies have also shown the same thing where men are less likely than women to support formal help with depressive symptoms (Wendt \& Shafer, 2014). In addition, men have lower attitudes towards seeking psychological help than women, which is influenced by men's perceptions of masculinity, where there is a traditional view that being a man must be strong, not express emotions excessively, resilient, and independent so that this hinders the search for psychological help (Yousaf et al., 2015).

Based on the results of this study, several practical implications that can be offered are: 1) the need for information to the public regarding various forms of religious coping, where there are active and passive religious coping and the two types of coping have different impacts on psychological conditions and the intention to seek psychological help , 2) the need for an increase in positive and active religious coping, where individuals are expected to not just surrender to God but try first (actively) and carry out various positive strategies such as reframing and worshiping, where both types of religious coping contribute significantly to the intention seeking psychological help.

The limitation of this study is that there are obstacles in the data collection process because many respondents were reluctant to fill out questionnaires that were given online. The number of items on the scale, lack of supervision, and less tangible rewards made many respondents not willing to fill in. This makes it difficult for researchers to get a representation of the ideal number of each faculty and class of respondents. In UB, the data collection process is done offline.

\section{Conclusion}

The results of this study indicate several important findings, 1) religious coping is a significant predictor of the intention to seek psychological help, while religiousity is not, 2) religious aspects of coping that are significant predictors of the intention to seek psychological help are a full assessment of wisdom, negative feelings towards God, and passive coping, 3) there are different predictors of psychological help-seeking intentions based on the type of university (Islamic public and private), where in subjects at Islamic private 
universities, religiousity, and religious coping significantly predict psychological helpseeking intentions, while the private university does not occur.

The most important finding of this study was not like previous studies, religiousity was not a significant predictor of psychological help-seeking intentions, and differences in the subject background (Islamic public and private universities), contributed differently to psychological help-seeking intentions.

\section{References}

Abe-Kim, J., Gong, F., \& Takeuchi, D. (2004a). Religiousity, spirituality, and help-seeking among filipino americans: Religious clergy or mental health professionals? Journal of Community Psychology, 32(6), 675-689. https://doi.org/10.1002/jcop.20026

Abe-Kim, J., Gong, F., \& Takeuchi, D. (2004b). Religiousity, spirituality, and help-seeking among filipino americans: Religious clergy or mental health professionals? Journal of Community Psychology, 32(6), 675-689. https://doi.org/10.1002/jcop.20026

Aflakseir, A., \& Coleman, P. G. (2011). Initial Development of the Iranian Religious Coping Scale. VI(1), 44-61.

Ajzen, I. (2012). Theories of Social Psychology. In P. A. M. Van Lange, A. W. Kruglanski, \& E. T. Higgins (Eds.), The Theory of Planned Behavior (Vol. 1, pp. 438-458). Sage Publication.

Al-Darmaki, F. R., Thomas, J., \& Yaaqeib, S. (2016). Mental Health Beliefs Amongst Emirati Female College Students. Community Mental Health Journal, 52(2), 233-238. https://doi.org/10.1007/s10597-0159918-9

Al-Krenawi, A., Graham, J. R., Dean, Y. Z., \& Eltaiba, N. (2004). Cross-National Study of Attitudes Towards Seeking Professional Help: Jordan, United Arab Emirates (UAE) and Arabs in Israel. International Journal of Social Psychiatry, 50(2), 102-114. https://doi.org/10.1177/00207640040409 57

Badan Penelitian dan Pengembangan Kesehatan Kementerian Kesehatan RI. (2018). Riset Kesehatan Dasar Republik Indonesia 2018.

Brown, J. S. L., Evans-Lacko, S., Aschan, L., Henderson, M. J., Hatch, S. L., \& Hotopf, M. (2014). Seeking informal and formal help for mental health problems in the community: A secondary analysis from a psychiatric morbidity survey in South London. BMC Psychiatry, 14(1), 1-15. https://doi.org/10.1186/s12888-0140275-y

Cepeda-Benito, A., \& Short, P. (1998). Selfconcealment, avoidance of psychological services, and perceived likelihood of seeking professional help. Journal of Counseling Psychology, 45(1), 58-64. https://doi.org/10.1037/00220167.45.1.58

Crosby, J. W., \& Bossley, N. (2012). The religiousity gap: preferences for seeking help from religious advisors. Mental Health, Religion \& Culture, 15(2), 141159.

https://doi.org/10.1080/13674676.2011.5 61485

Diana, N., Mahudin, M., Noor, N. M., Dzulkifli, M. A., \& Shari, N. (2016). Religiousity among Muslims: A Scale Development and Validation Study. Makara Hubs-Asia, 20(2), 109-120. https://doi.org/10.7454/mssh.v20i2.3492

Fischer, E. H., \& Turner, J. I. (1970). Orientations to seeking professional help: Development and research utility of an attitude scale. Journal of Consulting and Clinical Psychology, 35(1, Pt.1), 79-90. 
https://doi.org/10.1037/h0029636

Hammer, J. H., \& Spiker, D. A. (2018). Dimensionality, reliability, and predictive evidence of validity for three helpseeking intention instruments: ISCI, GHSQ, and MHSIS. Journal of Counseling Psychology, 65(3), 394-401. https://doi.org/10.1037/cou0000256

Hardika, Y. (2020). Bolehkah Membuka Aib Pribadi Saat Curhat atau Minta Solusi Pada Orang Lain? Ini Kata Buya Yahya. Serambinews.Com.

https://aceh.tribunnews.com/2020/12/17/ bolehkah-membuka-aib-pribadi-saatcurhat-atau-minta-solusi-pada-oranglain-ini-kata-buya-yahya?page $=3$

Kelly, A. E., \& Achter, J. A. (1995). Selfconcealment and attitudes toward counseling in university students. Journal of Counseling Psychology, 42(1), 40-46. https://doi.org/10.1037/00220167.42.1.40

Liao, H., Rounds, J., \& Klein, A. G. (2005). A Test of Cramer 's ( 1999 ) Help-Seeking Model and Acculturation Effects With Asian and Asian American College Students. 52(3), 400-411. https://doi.org/10.1037/00220167.52.3.400

Loewenthal, K. M., Cinnirella, M., Evdoka, G., \& Murphy, P. (2001). Faith conquers all? Beliefs about the role of religious factors in coping with depression among different cultural-religious groups in the UK. British Journal of Medical Psychology, 74, 293-303.

Mabruroh. (2020). Benarkah Depresi Berhubungan dengan Tingkat Keimanan. Republika.Co.Id. https://www.republika.co.id/berita/qhi63 6366/benarkah-depresi-berhubungandengan-tingkat-keimanan

Mayers, C., Leavey, G., Vallianatou, C., \& Barker, C. (2007). How clients with religious or spiritual beliefs experience psychological help-seeking and therapy: a qualitative study. Clinical Psychology and Psychotherapy, 14(4), 317-327.

Mechanic, D. (1962). Students under stress: A study of the social psychology of adaptation. In Students under stress: A study of the social psychology of adaptation. Free Press Glencoe.

Moreno, O., Nelson, T., \& Cardemil, E. (2017). Religiousity and attitudes towards professional mental health services: analysing religious coping as a mediator among Mexican origin Latinas/os in the southwest United States. Mental Health, Religion and Culture, 20(7), 626-637.

https://doi.org/10.1080/13674676.2017.1 372735

Niegocki, K. L., \& Ægisdóttir, S. (2019). College Students' Coping and Psychological Help-Seeking Attitudes and Intentions. Journal of Mental Health Counseling, 41(2), 144-157. https://doi.org/10.17744/mehc.41.2.04

Pargament, K., Feuille, M., \& Burdzy, D. (2011). The Brief RCOPE: Current Psychometric Status of a Short Measure of Religious Coping. Religions, 2, 51-76. https://doi.org/10.3390/rel2010051

Pheko, M. M., Chilisa, R., Balogun, S. K., \& Kgathi, C. (2013). Predicting Intentions to Seek Psychological Help Among Botswana University Students : The Role of Stigma and Help-Seeking Attitudes. SAGE-Open, $1-11$. https://doi.org/10.1177/21582440134946 55

Phillips III, R. E., Pargament, K. I., Lynn, Q. K., \& Crossley, C. D. (2004). SelfDirecting Religious Coping: A Deistic God, Abandoning God, or No God at All? Journal for the Scientific Study of Religion, 43(3), 409-418. https://doi.org/10.1111/j.14685906.2004.00243.x 
Raiya, H. A., Pargament, K. I., Mahoney, A., \& Stein, C. (2008). A Psychological Measure of Islamic Religiousness: Development and Evidence for Reliability and Validity. 291-315. https://doi.org/10.1080/10508610802229 270

Rogers-Sirin, L., Yanar, C., Yüksekbaş, D., Senturk, M. I., \& Sirin, S. (2017). Religiousity, Cultural Values, and Attitudes Toward Seeking Psychological Services in Turkey. Journal of CrossCultural Psychology, 48(10), 1587-1604. https://doi.org/10.1177/00220221177325 32

Rougier, C. (2011). Cultural Values Religiousity and Spirituality as Predictors of Professional Psychological Help-Seeking Behavior of Black Adults in the United States. Columbia University.

Sabina, C., Cuevas, C. A., \& Schally, J. L. (2012). The Cultural Influences on Helpseeking Among a National Sample of Victimized Latino Women. American Journal of Community Psychology, 49(34), $347-363$. https://doi.org/10.1007/s10464-0119462-x

Salsabila, D. F., Rofifah, R., Natanael, Y., \& Ramdani, Z. (2019). Uji Validitas Konstruk Indonesian-Psychological Measurement of Islamic Uji Validitas Konstruk Indonesian-Psychological Measurement of Islamic Religiousness ( I-PMIR ). Jurnal Psikologi Islam Dan Budaya, 2(2), 1-10. https://doi.org/10.15575/jpib.v2i2.5494

Sosulski, M. R., \& Woodward, A. T. (2013). African American Women Living with Mental Disorders: Factors Associated with Help Seeking from Professional Services and Informal Supports. Social Work in Public Health, 28(7), 660-671. https://doi.org/10.1080/19371918.2011.5 93462
Sulistyani, D., Supradewi, R., \& Syafitri, D. U. (2018). Hubungan Antara Koping Religius dengan Penyesuaian Diri Pada Mahasiswa Tingkat Awal di Universitas Islam Sultan Agung Semarang. Universitas Islam Sultan Agung.

Syafitri, D. U. (2018). Literasi Kesehatan Mental Mahasiswa di Kota Semarang. In Research Reports of Faculty of Psychology Sultan Agung Islamic University.

Syafitri, D. U. (2019). Perilaku mencari bantuan psikologis pada mahasiswa universitas islam sultan agung semarang.

Syafitri, D. U., \& Kusumaningsih, L. P. S. (2021). Sikap terhadap bantuan psikologis (tatap muka dan daring) ditinjau dari penyembunyian diri, harapan pengungkapan, dan stigma diri pada mahasiswa. Jurnal Ilmiah Psikologi Terapan, $9(1), \quad 84$. https://doi.org/10.22219/jipt.v9i1.14151

Syafitri, D. U., \& Wijayanti, N. (2017). Pentingnya Literasi Kesehatan Mental Sebagai Upaya Peningkatan Kualitas Hidup Masyarakat. Seminar Nasional BAPPEDA: Inovasi Dan Kreasi Memajukan Jawa Tengah, 1087-1095.

Turner, N., Hastings, J. F., \& Neighbors, H. W. (2019). Mental health care treatment seeking among African Americans and Caribbean Blacks: what is the role of religiousity/spirituality? Aging and Mental Health, 23(7), 905-911. https://doi.org/10.1080/13607863.2018.1 453484

Wamser, R., Vandenberg, B., \& Hibberd, R. (2011). Religious fundamentalism, religious coping, and preference for psychological and religious treatment. International Journal for the Psychology of Religion, 21(3), 228-236. https://doi.org/10.1080/10508619.2011.5 81582

Wang, S., Wang, J., Li, J., \& Zhou, K. (2020). 
How and when does religiousity contribute to tourists' intention to behave pro-environmentally in hotels? Journal of Sustainable Tourism, 28(8), 1120-1137. https://doi.org/10.1080/09669582.2020.1 724122

Wendt, D., \& Shafer, K. (2014). Gender and Attitudes about Mental Health Help Seeking: Results from National Data. Health and Social Work, 41(1), e20-e28. https://doi.org/10.1093/hsw/hlv089

Woodward, A. T., Taylor, R. J., \& Chatters, L. M. (2012). Use of Professional and Informal Support by Black Men with Mental Disorders. Research on Social Work Practice, 23(1), 1-7. https://doi.org/10.1177/10497315103886 68.Use

Yousaf, O., Popat, A., \& Hunter, M. S. (2015). An investigation of masculinity attitudes, gender, and attitudes toward psychological help-seeking. Psychology of Men and Masculinity, 16(2), 234-237. 